Article

\title{
Decomposition of a $\beta-0-4$ lignin model compound over solid Cs-substituted polyoxometalates in anhydrous ethanol: acidity or redox property dependence?
}

\author{
Xuezhong $\mathrm{Wu}^{\mathrm{a}, \mathrm{b}}$, Wenqian Jiao a, Bing-Zheng Li ${ }^{\mathrm{b}}$, Yanming Li ${ }^{\mathrm{b}}$, Yahong Zhang a, Quanrui Wang c, \\ Yi Tang a,* \\ a Department of Chemistry, Laboratory of Advanced Materials, Collaborative Innovation Center of Chemistry for Energy Materials and Shanghai Key \\ Laboratory of Molecular Catalysis and Innovative Materials, Fudan University, Shanghai 200433, China \\ b State Key Laboratory of Non-Food Biomass Enzyme Technology, National Engineering Research Center for Non-Food Biorefinery, Guangxi Key \\ Laboratory of Biorefinery, Guangxi Academy of Sciences, Nanning 530007, Guangxi, China \\ c Department of Chemistry, Fudan University, Shanghai 200433, China
}

\section{A R T I C L E I N F}

\section{Article history:}

Received 26 March 2017

Accepted 30 April 2017

Published 5 July 2017

\section{Keywords:}

Lignin model compound

$\beta-0-4$ ether bond

Polyoxometalate

Hydrogen transfer mechanism

Oxonium cation mechanism

Anhydrous ethanol

\begin{abstract}
A B S T R A C T
Production of aromatics from lignin has attracted much attention. Because of the coexistence of $\mathrm{C}-\mathrm{O}$ and $\mathrm{C}-\mathrm{C}$ bonds and their complex combinations in the lignin macromolecular network, a plausible roadmap for developing a lignin catalytic decomposition process could be developed by exploring the transformation mechanisms of various model compounds. Herein, decomposition of a lignin model compound, 2-phenoxyacetophenone (2-PAP), was investigated over several cesium-exchanged polyoxometalate (Cs-POM) catalysts. Decomposition of 2-PAP can follow two different mechanisms: an active hydrogen transfer mechanism or an oxonium cation mechanism. The mechanism for most reactions depends on the competition between the acidity and redox properties of the catalysts. The catalysts of POMs perform the following functions: promoting active hydrogen liberated from ethanol and causing formation of and then temporarily stabilizing oxonium cations from 2-PAP. The use of Cs-PMo, which with strong redox ability, enhances hydrogen liberation and promotes liberated hydrogen transfer to the reaction intermediates. As a consequence, complete conversion of 2-PAP (>99\%) with excellent selectivities to the desired products $(98.6 \%$ for phenol and $91.1 \%$ for acetophenone) can be achieved.
\end{abstract}

(C) 2017, Dalian Institute of Chemical Physics, Chinese Academy of Sciences. Published by Elsevier B.V. All rights reserved.

\section{Introduction}

With depletion of fossil fuels and exacerbation of haze weather and globe warming, sustainable development has been highlighted by many governments [1,2]. Production of fuels and chemicals from bioresources is reasonable and practicable
[3-5]. Lignocellulose is an inedible, almost inexhaustible [6], and consistently renewable bioresource that can be used to produce energy and chemicals. As the second principal component of lignocellulose, lignin can be used as a precursor for fuels and aromatic chemicals because it is the only naturally occurring aromatic polymer [7]. However, the potential of lig-

\footnotetext{
* Corresponding author. Tel: +86-21-55664125; Fax: +86-21-65641740; E-mail: yitang@fudan.edu.cn

This work was supported by the National Key Basic Research Program of China (973 program, 2013CB934101), National Natural Science Foundation of China (21433002, 21573046), China Postdoctoral Science Foundation (2016M601492), and International Science and Technology Cooperation Projects of Guangxi (15104001-5).

DOI: 10.1016/S1872-2067(17)62854-7 | http://www.sciencedirect.com/science/journal/18722067 | Chin. J. Catal., Vol. 38, No. 7, July 2017
} 
nin has not been fully realized. Most lignin is directly burned in alkali recovery systems. Only a small amount of lignin is separated and used to produce dispersants or adhesives, and an even smaller amount is used to produce value-added chemicals [8-10]. With the development of catalytic technologies, preparation of bulk or fine aromatics from lignin is essential and perhaps the most promising use of lignin, and this ambitious objective has attracted tremendous research interest [11-13].

Because of its stable three-dimensional network structure and the robust complicated chemical associations among the monolignans, it is still a great challenge to selectively convert lignin to value-added chemicals $[11,14]$. Some achievements have been made in recent years [15-24], and many scientists have studied hydrogenolysis of $\mathrm{C}-0$ linkages in lignin with various hydrogen sources over metal catalysts [17,25-28]. Song et al. [15] used a Ni/C catalyst to depolymerize native lignin in methanol dispersant. They achieved high conversion and selectivity, which opens up a new pathway for lignin transformation and has methodological significance. Ma et al. [16] completely ethanolyzed Kraft lignin over an $\alpha-\mathrm{MoC}_{1-x} / \mathrm{AC}$ catalyst in pure ethanol at $280{ }^{\circ} \mathrm{C}$ to give low molecular mass chemicals. Konnerth et al. [29] used bimetallic $\mathrm{Ni}_{7} \mathrm{Au}_{3}$ nanoparticles to hydrogenolyze a lignin model compound and organosolv lignin in alkaline surroundings. Various acids have also been used as catalysts to produce phenols from alkaline lignin $[20,30]$.

To take full advantage of lignin and prepare valuable multi-substituted benzenes or their derivatives with reasonable selectivity, a rational catalytic process to selectively cleave the linkages between the monolignans needs to be developed. Nevertheless, owing to the coexistence of complex C-O and C-C bonds and the complicated combinations in the macromolecular structure, it is very challenging to directly investigate the mechanism of the decomposition process of technical lignin. It is more reasonable to first investigate the cleavage mechanisms of various lignin model compounds with specific linkages, and then consider extension from micro- to macromolecule systems $[15,31]$ to finally achieve the objective of rational design of catalytic materials and development of the catalytic process for decomposition of technical lignin to valuable aromatics. Among the linkages of monolignans, the $\beta-0-4$ linkage accounts for the majority of the linkages in natural lignin and even in some technical lignins, such as lignin obtained from bioethanol refinery where $\beta-0-4$ linkages are still largely preserved [33,34]. 2-Phenoxyacetophenone (2-PAP) was selected as the model for the $\beta-0-4$ linkage because this linkage represents some partially oxidized lignins $[11,35,36]$ and the amount of partially oxidized lignin has increased as $\mathrm{C}-\mathrm{C}$ bond cleavage technology roadmaps have recently emerged [37-40].

Polyoxometalates (POMs) are widely applied as acid catalysts [41]. Recently, several POMs have been used for homogeneous or heterogeneous catalytic conversion of lignin or its model compounds [30,42]. Soluble lignin and model compounds have also been oxidized to benzoquinones over several soluble POM catalysts with $\mathrm{H}_{2} \mathrm{O}_{2}$ as the oxidant [42]. $\mathrm{Li}$ and co-workers [30] used soluble and supported $\mathrm{H}_{4} \mathrm{PW}_{12} \mathrm{O}_{40}$ catalysts to depolymerize Kraft lignin to phenols with a high yield of $67 \mathrm{mg} / \mathrm{g}$. Park et al. [43] used a cesium-exchanged phospho- tungstic acid (Cs-PW) catalyst to cleave an $\alpha-0-4$ model compound to aromatics. Although some great achievements have been made in hydrogenolysis and acidolysis cleavage of the $\beta-0-4$ ether bond in lignin or its model compounds, the effect of cooperation or competition between the acidity and redox properties of the catalyst on the cleavage and its mechanism are not clear.

Herein, several Cs-substituted POMs were selected to systematically investigate the effects of the acidity and redox properties of the acid catalyst on the cleavage of the lignin model compound 2-PAP. A comprehensive hydrogen transfer and acid-catalyzed mechanism are proposed based on the catalytic performance over these catalysts. These results will be useful for understanding the reaction phenomena and designing a practicable process for decomposition of technical lignin.

\section{Experimental}

\subsection{Materials}

The model compound 2-PAP was purchased from TCI Chemicals (Shanghai, China). Anhydrous ethanol (AE), phenol, acetophenone, $\quad \mathrm{H}_{3} \mathrm{PMo}_{12} \mathrm{O}_{40} \cdot x \mathrm{H}_{2} \mathrm{O}, \quad \mathrm{H}_{3} \mathrm{PW}_{12} \mathrm{O}_{40} \cdot x \mathrm{H}_{2} \mathrm{O}$, $\mathrm{H}_{4} \mathrm{SiW}_{12} \mathrm{O}_{40} \cdot x \mathrm{H}_{2} \mathrm{O}$, and cesium nitrate $\left(\mathrm{CsNO}_{3}\right.$ ) (all of analytical purity) were purchased from Sinopharm Chemical Reagent Co., Ltd. (Shanghai, China). They were used as received without further purification.

\subsection{Preparation of the solid POMs}

Cs-substituted POMs were prepared by the ion exchange method described by Park et al. [44]. The phase structures of the POM salts were determined by powder X-ray diffraction (XRD), Fourier transform infrared (FT-IR) spectroscopy, and Raman spectroscopy (Figs. 1-3). These characterizations of the Cs-POMs verified that crystals were successfully prepared with the phase of the Keggin structure [10,45-52]. All of products were kept in a desiccator before use.

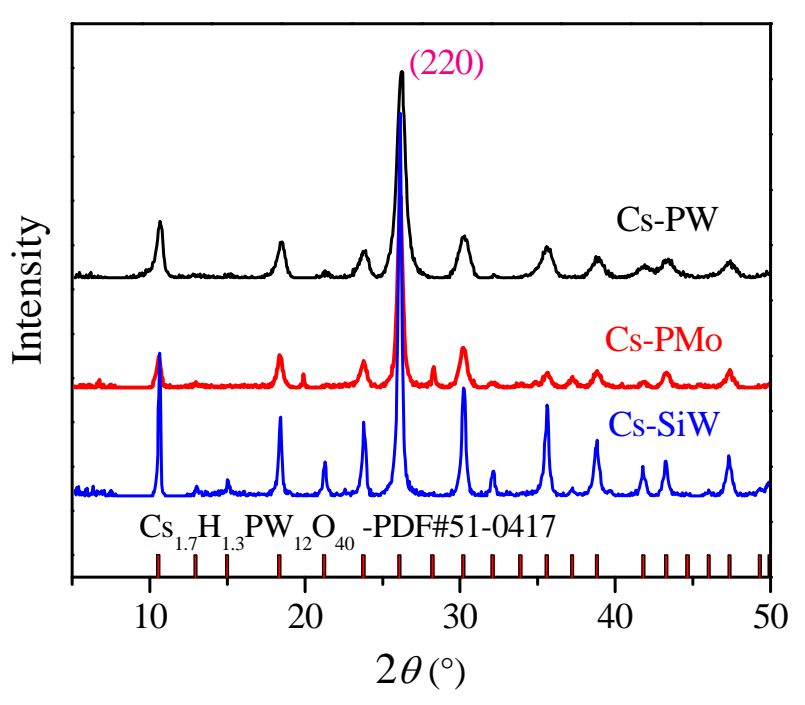

Fig. 1. XRD patterns of the Cs-POMs. 


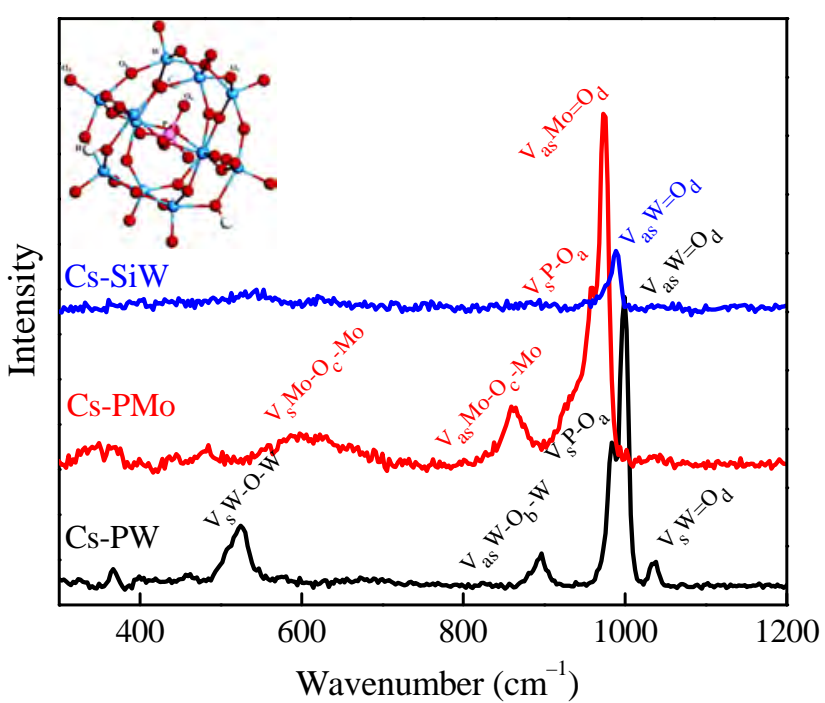

Fig. 2. Raman spectra of the POMs $\left(\mathrm{O}_{\mathrm{a}}\right.$ central tetrahedron oxygen, $\mathrm{O}_{\mathrm{b}}$ corner oxygen, $\mathrm{O}_{\mathrm{d}}$ terminal oxygen, $\mathrm{O}_{\mathrm{e}}$ edge-shared oxygen).

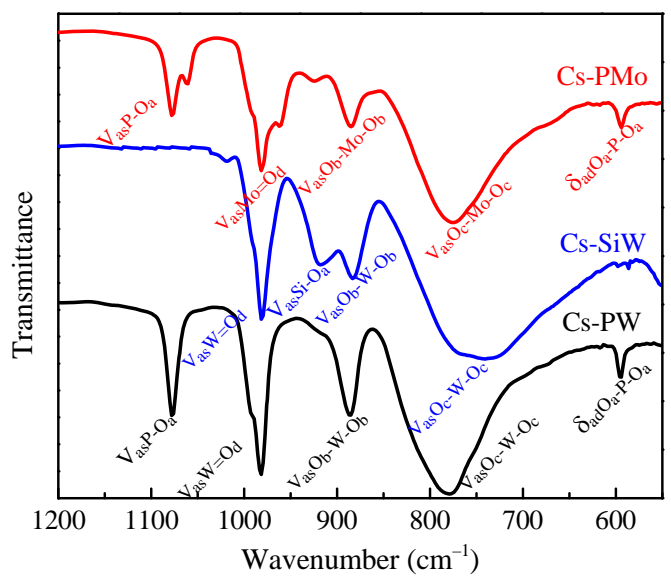

Fig. 3. FT-IR spectra of the POMs.

\subsection{Characterization of the solid POMs}

The solid POMs were characterized by XRD, FT-IR spectroscopy, Raman spectroscopy, $\mathrm{NH}_{3}$-temperature programmed reduction ( $\left.\mathrm{NH}_{3}-\mathrm{TPD}\right), \mathrm{H}_{2}$ temperature programmed reduction ( $\mathrm{H}_{2}$-TPR), and X-ray photoelectron spectroscopy (XPS). The XRD patterns were collected with a D8 Advance Plus X-ray diffractometer (Bruker, Germany) using a $\mathrm{Cu} K_{\alpha}$ radiation source and recorded in the $2 \theta$ range $5^{\circ}-50^{\circ}$ at a scanning speed of 10 $\%$ min. The FT-IR spectra of the POMs were recorded with a Nicolet IS10 infrared spectrometer (Thermo Scientific, USA) and acquired by the transmission method. The Raman spectra were collected using an XploRA Raman spectrometer (Horiba Jobin Yvon, France) with $532 \mathrm{~nm}$ laser excitation under ambient conditions. The $\mathrm{NH}_{3}$-TPD profiles were collected with an Autochem II chemisorption instrument (Micromeritics, USA) with a thermal conductivity detector and a cold trap. The adsorption temperature of ammonia was $100{ }^{\circ} \mathrm{C}$ and the ramp speed was $10{ }^{\circ} \mathrm{C} / \mathrm{min}$. Before the experiments, the catalysts were activated in helium at $250{ }^{\circ} \mathrm{C}$ for $2 \mathrm{~h}$. The $\mathrm{H}_{2}$-TPR profiles were obtained with an Autochem II chemisorption instrument (Micromeritics, USA) equipped with a thermal conductivity detector and a cold trap. Before the experiments, the catalysts were activated in argon $250{ }^{\circ} \mathrm{C}$ for $2 \mathrm{~h}$. The XPS data were acquired with an Axis Ultra Dld spectrometer (Shimadzu, Japan) with $\mathrm{Mg} K_{\alpha}$ radiation as the excitation source. All of binding energy values were referenced to the $\mathrm{C} 1 s$ peak at $284.6 \mathrm{eV}$.

\subsection{Decomposition of the lignin model compound}

The decomposition reactions were performed in a T316 stainless-steel autoclave equipped with a controller, a thermocouple, and a mechanical agitator (Model 4598, Parr Instrument Company, Moline, USA). The reactions were typically performed by first introducing $0.100 \mathrm{~g}$ of 2-PAP and $0.010 \mathrm{~g}$ of the catalyst (or no catalyst) into the dry autoclave, and then 50 $\mathrm{mL}$ of $\mathrm{AE}$ was introduced. The autoclave was quickly closed to prevent adsorption of water and then purged with $\mathrm{N}_{2}$ several times. The reaction was performed at $280^{\circ} \mathrm{C}$ for $4 \mathrm{~h}$ with a stirring speed of $300 \mathrm{r} / \mathrm{min}$. After a predetermined time, the reactor was cooled to room temperature and the products were then collected for further analysis [53].

\subsection{Product analysis}

The products were first analyzed by gas chromatography-mass spectroscopy (GC-MS, Model DSQ II, Thermo Fisher, Austin, USA), and then analyzed using a GC flame ionization detector (GC-FID) equipped with a HP-5 column (GC-2010, Shimadzu, Japan). The concentrations of 2-PAP, POPE, phenol, and acetophenone were determined by the external standard method. The 2-PAP conversion, selectivities for phenol and acetophenone, and total mass yield of all other products (wt $\%$ ) were calculated by the following equations:

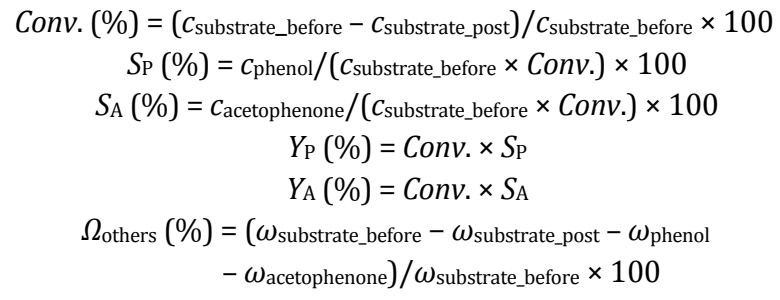
where Conv. is conversion of the 2-PAP substrate, $S_{\mathrm{P}}$ and $S_{\mathrm{A}}$ are the selectivities of phenol and acetophenone, respectively, $Y_{\mathrm{P}}$ and $Y_{\mathrm{A}}$ are the productivities of phenol and acetophenone, respectively, $\Omega_{\text {others }}$ is the total mass yield of products other than phenol and acetophenone, $c$ is the molar concentration of the specific compound calculated by the chromatographic peak area in the GC-FID chart of the reaction products that correspond to the external standards of a specific compound (mol/L), and $\omega$ is the mass concentration of a specified compound $(\mathrm{g} / \mathrm{L})$.

\subsection{Determination of the loss of solid POMs in the solvent}

Loss of the solid POMs in the AE solvent was analyzed by inductively 
Table 1

Loss of POMs in the AE solvent determined by ICP-AES.

\begin{tabular}{lrrrrr}
\hline \multirow{2}{*}{ Catalyst } & \multicolumn{4}{c}{ Detected concentration $(\mathrm{mg} / \mathrm{L})$} & \multirow{2}{*}{ Theoretical loss ratio $^{\text {a }}$} \\
\cline { 2 - 5 } & $\mathrm{Mo}$ & $\mathrm{W}$ & \multicolumn{1}{c}{$\mathrm{P}$} & $\mathrm{Si}$ & $(\%)$ \\
\hline Cs-PMo & 0.05 & $<0.01$ & $<0.02$ & 0.92 & 0.22 \\
Cs-PW & 0.03 & 0.12 & 0.02 & 0.55 & 0.27 \\
Cs-SiW & $<0.01$ & $<0.01$ & $<0.02$ & 0.25 & $<0.023$ \\
\hline
\end{tabular}

a Theoretical loss ratio (\%) $=c_{\text {detected }} / c_{\text {theoretical, }}$ where $c_{\text {detected }}$ is the detected concentration of the coordination atoms in the post-reaction solution and $c_{\text {theoretical }}$ is the concentration of the coordination atoms in the POM, which is assumed to completely dissolve in the solution before the reaction.

coupled plasma-atomic emission spectrometry (ICP-AES; Model iCAP6300, Thermo Fisher, USA). About $20 \mathrm{~mL}$ of the AE solvent was withdrawn in a clean crucible before and after the reaction. The solvent samples were first acidified by $\mathrm{HNO}_{3}$ solvent and then air-dried at room temperature. The crucible was then calcined at $500{ }^{\circ} \mathrm{C}$ for $6 \mathrm{~h}$ in air. $\mathrm{HNO}_{3}$ solvent $(20 \mathrm{~mL}, 1 \mathrm{~mol} / \mathrm{L})$ was then introduced into the crucible and the crucible was kept in an ultrasonic machine for $30 \mathrm{~min}$. Finally, the metals in this ultrasonic treated solvent were determined by ICP-AES. The results are given in Table 1. Almost none of the solid POMs are lost in the solvent during the reactions.

\section{Results and discussion}

\subsection{Characterization of the Cs-POMs}

\subsubsection{Acidity of the Cs-POMs}

The $\mathrm{NH}_{3}$-TPD method was used to evaluate the acidity of the POMs. Their profiles are shown in Fig. 4. The acid amounts and strengths of the three samples are very different. Cs-PMo shows reasonably strong acidity with an ammonia desorption peak in the temperature range $250-400{ }^{\circ} \mathrm{C}$, while Cs-SiW shows stronger acidity with the ammonia desorption temperature mainly in the range $450-550{ }^{\circ} \mathrm{C}$. Cs-PW shows the strongest acidity among the three samples, and part of the adsorbed ammonia did not desorb even at a temperature higher than $550{ }^{\circ} \mathrm{C}$. These results are consistent with the literature [41,54]. Table 2 lists the amounts of acid sites calculated from the peak areas in Fig. 4. The acid site amounts per gram verify

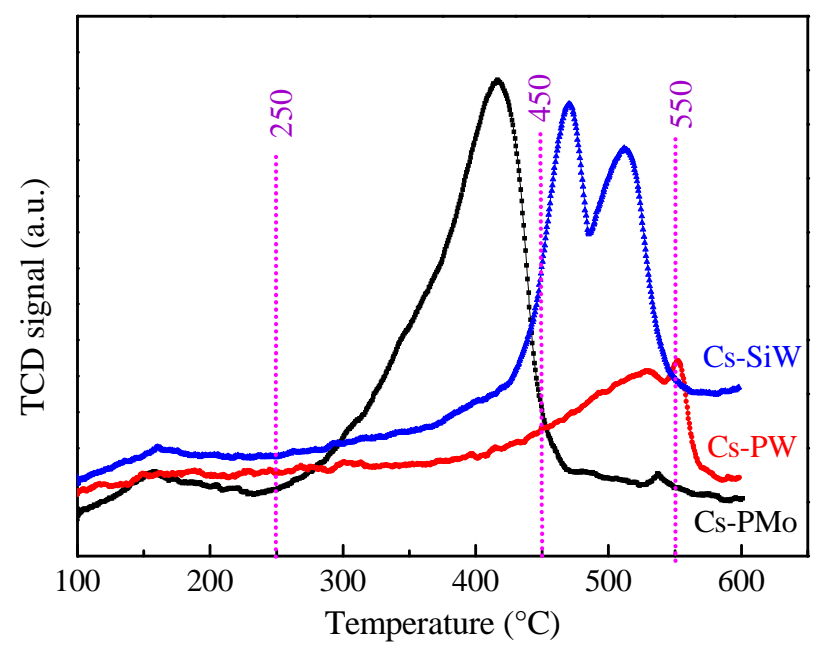

Fig. 4. $\mathrm{NH}_{3}$-TPD profiles of the POMs.
Table 2

Total amounts of acid sites of the POMs calculated by $\mathrm{NH}_{3}$-TPD.

\begin{tabular}{lcc}
\hline \multirow{2}{*}{ Catalyst } & \multicolumn{2}{c}{ Total acidic amount } \\
\cline { 2 - 3 } & $(\mathrm{mmol} / \mathrm{g})$ & $(\mathrm{mol} / \mathrm{mol})$ \\
\hline Cs-PMo & 0.43 & 0.92 \\
Cs-PW & 0.18 & 0.57 \\
Cs-SiW & 0.29 & 0.92 \\
\hline
\end{tabular}

that the acidities of Cs-PMo and Cs-SiW are much higher than that of Cs-PW. Furthermore, the amount of acid sites of Cs-PMo exceeds that of Cs-SiW (Table 2). According to the molar mass, the amount of acid sites of Cs-PMo is the same as that of Cs-SiW, but nearly twice that of Cs-PW.

\subsubsection{Redox properties of the POMs}

The redox properties of the three POMs were evaluated by $\mathrm{H}_{2}$-TPR, and the profiles are shown in Fig. 5. There are no consumption peaks below $300{ }^{\circ} \mathrm{C}$, indicating no adsorption of $\mathrm{H}_{2}$ to the POM catalysts in this temperature range. The TPR profile of Cs-PMo shows distinct $\mathrm{H}_{2}$ consumption peaks in the temperature range 350 to $500{ }^{\circ} \mathrm{C}$. This indicates that there is considerable reduction from $\mathrm{MoO}_{3}$ to $\mathrm{MoO}_{2}$ in this temperature range because molybdena can be partly formed at a TPR temperature of about $400{ }^{\circ} \mathrm{C}[55,56]$. The TPR profiles of Cs-PW and Cs-SiW show an increasing tendency as the TPR temperature increases above $350^{\circ} \mathrm{C}$ and their response signals are much weaker than that of Cs-PMo, indicating that Cs-PW and Cs-SiW are much more difficult to be reduced than Cs-PMo [41,54].

The redox properties of the catalysts were further investigated by XPS experiments. Fig. 6 shows the high-resolution Mo $3 d$ and W $4 f$ XPS spectra of Cs-PMo and Cs-PW before and after treatment in $\mathrm{AE}$ at $280^{\circ} \mathrm{C}$ for $4 \mathrm{~h}$, respectively. The curve-fitting procedure (Fig. 6(a)) reveals a doublet peak of Mo(VI) $\left(3 d_{5 / 2} / 3 d_{3 / 2}\right)$ in untreated Cs-PMo at $232.9 / 236.2 \mathrm{eV}$, and doublet peaks at 232.9/236.2 and 231.0/234.8 eV for Mo(VI) and Mo(IV) $\left(3 d_{5 / 2} / 3 d_{3 / 2}\right)$ in treated Cs-PMo, respectively $[57,58]$. These peaks indicate that $\mathrm{Mo}(\mathrm{VI})$ in the crystals of Cs-PMo is partially reduced during treatment in AE. Fig. 6(b) shows the results for Cs-PW before and after treatment under the same

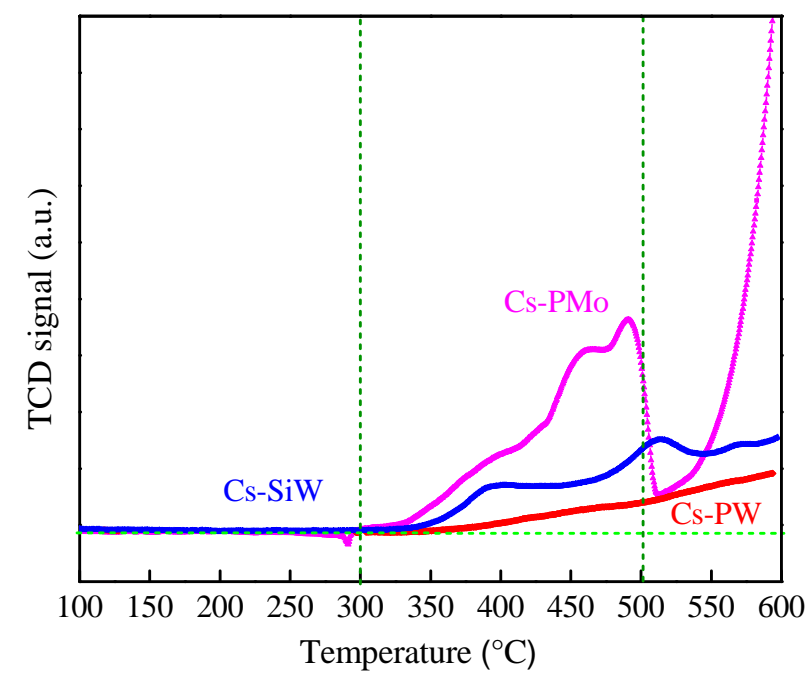

Fig. 5. $\mathrm{H}_{2}$-TPR profiles of the POMs. 

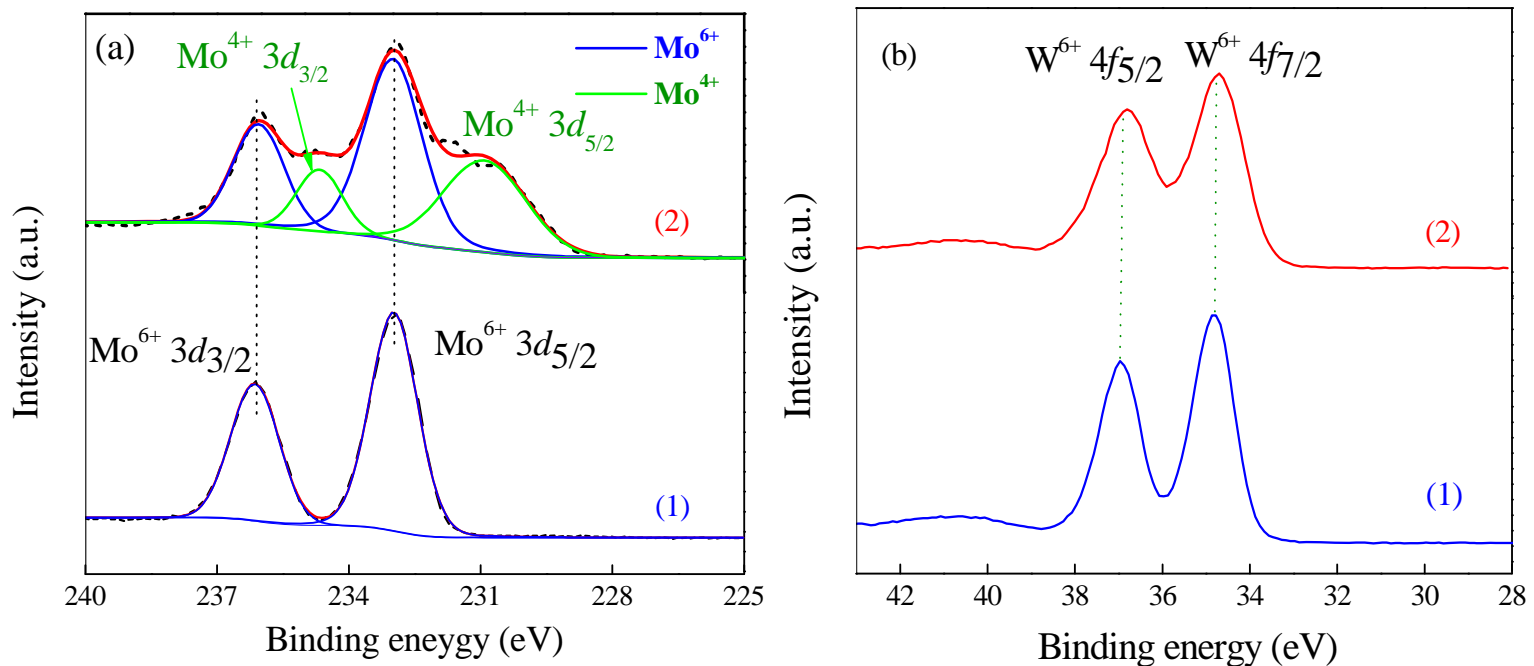

Fig. 6. High-resolution Mo $3 d$ and W $4 f$ XPS spectra with signal fitting analysis: (a) Cs-PMo and (b) Cs-PW before (1) and after (2) treatment in AE at $280^{\circ} \mathrm{C}$ for $4 \mathrm{~h}$.

conditions. The curve-fitting procedure reveals that the spectra of Cs-PW show a doublet at $34.8 / 37.0 \mathrm{eV}$ for W(VI) $\left(4 f_{7} / 2,4 f_{5} / 2\right)$ components both before and after treatment $[59,60]$. This indicates that W(VI) in the crystals of Cs-PW is not reduced during the treatment in AE. Therefore, the Cs-PMo catalyst is a bifunctional catalyst with redox and acidic properties, while the Cs-PW catalyst only acts as a monofunctional acid catalyst in our reactions.

\subsection{Conversion of 2-PAP over the POMs}

\subsubsection{Conversion and selectivity over the POM catalysts}

Cs-SiW, Cs-PW, and Cs-PMo were used to investigate their catalytic effect on decomposition of 2-PAP in AE at $280^{\circ} \mathrm{C}$ for 4 $\mathrm{h}$ in a T316SS autoclave with the stirring speed of $300 \mathrm{r} / \mathrm{min}$. Conversion of 2-PAP and the selectivities to the main products were determined by GC-FID with external standard methods. The results are given in Table 3 along with the results of the reaction without adding a catalyst for reference. It has been reported that 2-PAP can be decomposed in AE at high temperature in a T316SS autoclave. The stainless-steel wall of the T316SS autoclave could promote transfer of the hydrogen liberated from AE to 2-PAP and various decomposed intermediates. As shown in row 1 of Table 3, 2-PAP is almost completely converted even without adding a catalyst, and the selectivities of phenol and acetophenone are $81.6 \%$ and $54.4 \%$, respective- ly. The corresponding reaction mechanism has been described in our previous paper [53].

When Cs-PMo was added into the reaction system (row 2 of Table 3), 2-PAP was completely converted and the selectivities of phenol and acetophenone were $98.6 \%$ and $91.1 \%$, respectively. Only a small amount of others products $(<5 \mathrm{wt} \%)$ was produced. This result suggests that Cs-PMo has excellent catalytic activity for decomposition of 2-PAP to the target products in AE. However, it is surprising that conversion of 2-PAP was surprisingly low (89\%) when Cs-PW was used as a catalyst (row 3), and the selectivities for phenol and acetophenone also decreased to $65.5 \%$ and $47.7 \%$, respectively. These values are even lower than those without adding a catalyst. Cs-SiW performed even worse for this reaction, with selectivities for phenol and acetophenone of $40.7 \%$ and $11.3 \%$, respectively, and 2-PAP conversion of only $37.6 \%$.

\subsubsection{Product distribution of 2-PAP decomposition in $A E$ catalyzed by the POMs}

Analysis of the product distribution can reveal the details of the reaction, which are very useful for investigating the reaction mechanism. The GC-MS results of the reaction products with and without addition of a POM catalyst are shown in Table 4 , and their corresponding total ion current (TIC) profiles are shown in Fig. 7. As shown in rows 1-4 of Table 4, the products from dehydrogenation and/or intermolecular dehydration

Table 3

Product distributions of 2-PAP in AE with and without the Cs-POM catalysts ${ }^{\text {a. }}$

\begin{tabular}{|c|c|c|c|c|c|c|c|c|c|}
\hline \multirow{2}{*}{ Catalyst } & \multirow{2}{*}{ Temp. $\left({ }^{\circ} \mathrm{C}\right)$} & \multirow{2}{*}{ Conv. (\%) } & \multicolumn{2}{|c|}{ Phenol } & \multicolumn{2}{|c|}{ Acetophenone } & \multirow{2}{*}{$S_{\mathrm{P}} / S_{\mathrm{A}}$} & \multirow{2}{*}{$\Omega_{\text {others }}(\%)$} & \multirow{2}{*}{ Total area } \\
\hline & & & $Y_{\mathrm{P}}(\%)$ & $S_{\mathrm{P}}(\%)$ & $Y_{\mathrm{A}}(\%)$ & $S_{\mathrm{A}}(\%)$ & & & \\
\hline No catalyst & 280 & $>99$ & 81.2 & 81.6 & 54.1 & 54.4 & 1.5 & 33.0 & 847253 \\
\hline Cs-PMo & 280 & $>99$ & 98.6 & 98.6 & 91.1 & 91.1 & 1.1 & 4.6 & 5888967 \\
\hline Cs-PW & 280 & 88.8 & 58.2 & 65.5 & 42.4 & 47.7 & 1.4 & 39.0 & 1145881 \\
\hline Cs-SiW & 280 & 37.6 & 15.3 & 40.7 & 4.2 & 11.3 & 3.6 & 28.4 & 1257376 \\
\hline
\end{tabular}

a Reaction conditions: $0.100 \mathrm{~g}$ 2-PAP, $50 \mathrm{~mL} \mathrm{AE,} 280^{\circ} \mathrm{C}, \mathrm{N}_{2}$ atmosphere, reaction time $4 \mathrm{~h}, 0.010 \mathrm{~g}$ Cs-POM catalyst, stirring speed $300 \mathrm{r} / \mathrm{min}$.

${ }^{\mathrm{b}}$ Total area $=$ area $_{\text {ethoxyethene }}+$ area $_{\text {acetal. }}$. The areas are the peak areas of the chromatogram of GC-FID, and these areas are only used to reflect their corresponding tendencies with changing reaction conditions. Thus, they are not quantitatively useful. 
Table 4

Distribution of the main products from decomposition of 2-PAP in AE with POM catalysts a.

\begin{tabular}{|c|c|c|c|c|c|c|c|c|c|c|c|}
\hline Product & $\begin{array}{c}\text { No } \\
\text { catalyst }\end{array}$ & Cs-PMo & Cs-PW & Cs-SiW & $\mathrm{H}_{4} \mathrm{SiW}_{12} \mathrm{O}_{40}$ & Product & No catalyst & Cs-PMo & Cs-PW & Cs-SiW & $\mathrm{H}_{4} \mathrm{SiW}_{12} \mathrm{O}_{40}$ \\
\hline & trace & trace & trace & trace & trace & & u.d. & u.d. & d. & $\mathrm{d}$. & d. \\
\hline & d. ${ }^{b}$ & d. & d. & d. & d. & & u.d. & u.d. & d. & d. & d. \\
\hline & d. & d. & d. & d. & d. & & u.d. & u.d. & d. & u.d. & u.d. \\
\hline & d. & d. & d. & d. & d. & & u.d. & u.d. & u.d. & d. & $\begin{array}{l}\text { d.(Greatly } \\
\text { increased) }\end{array}$ \\
\hline & u.d. ${ }^{c}$ & d. & u.d. & u.d. & u.d. & & u.d. & u.d. & u.d. & d. & d. \\
\hline & d. & d. & d. & d. & d. & & u.d. & u.d. & u.d. & d. & d. \\
\hline & d. & d. & d. & d. & d. & & u.d. & u.d. & d. & d. & d. \\
\hline & d. & d. & d. & d. & d. & & d. & u.d. & u.d. & $\mathrm{d}$. & d. \\
\hline & d. & d. & d. & d. & d. & & d. & u.d. & d. & d. & d. \\
\hline & d. & u.d. & d. & d. & d. & & d. & d. & d. & d. & d. \\
\hline & d. & u.d. & u.d. & u.d. & u.d. & & d. & u.d. & d. & d. & d. \\
\hline
\end{tabular}

a Reaction conditions: $0.100 \mathrm{~g}$ 2-PAP, $50 \mathrm{~mL} \mathrm{AE}, 280^{\circ} \mathrm{C}, \mathrm{N}_{2}$ atmosphere, reaction time $4 \mathrm{~h}, 0.010 \mathrm{~g}$ of the POM catalyst, stirring speed $300 \mathrm{r} / \mathrm{min}$. Verified by GC-MS.

b Detected.

c Undetected.

reactions of the AE solvent are all detected, such as ethylal, ethoxyethene, diethyl ether, and acetal [53,61,62].

Except for the similar products from the ethanol solvent, there are large differences in the products from decomposition of 2-PAP. The products from decomposition of 2-PAP without a catalyst are styrene, phenol, acetophenone, ethyl benzoate, (1-ethoxyethyl)benzene, 4-(1-hydroxyethyl) benzaldehyde, 2-phenoxy-1-phenylethan-1-ol, and (2,4-dimethylphenyl)-2(4-methoxyphenyl) diazene (nitrides) (column 2 of Table 4 and Fig. 7). Their generation mechanisms have been described in our previous report as the result of hydrogen transfer reactions [53]. Production of nitrides can be ascribed to the reactions of the 2-PAP cleavage intermediates with the activated nitrogen in the autoclave.

When the reaction is catalyzed by Cs-PMo, in addition to similar products to those without a catalyst, a small amount of ethyl benzene is generated (column 3 of Table 4), while there are no products of nitrides, such as (2,4-dimethylphenyl)-2(4-methoxyphenyl)diazene. Generation of ethyl benzene can be attributed to excessive hydrogenation of styrene along route 

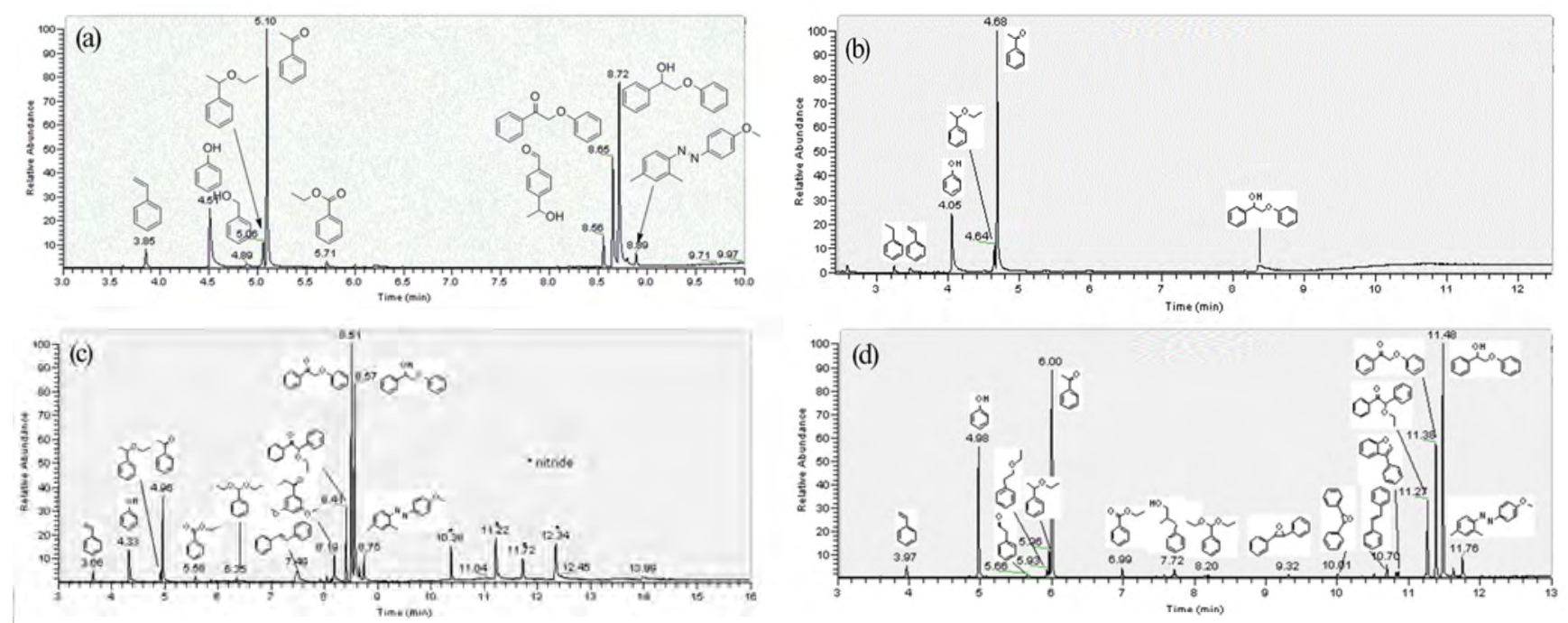

Fig. 7. TIC profiles of the reaction products of 2-PAP in AE with a stirring speed of $300 \mathrm{r} / \mathrm{min}$ with POM catalysts from GC-MS. (a) no catalyst; (b) Cs-PMo; (c) Cs-PW; (d) Cs-SiW.

Ia-1 in Scheme 2 in hydrogen-enriched surroundings [53], whereas the lack of nitrides can be attributed to greatly enhanced hydrogen donation (row 2 of Table 3). When the reaction is catalyzed by Cs-PW (row 3 of Table 3) or Cs-SiW (row 4 of Table 3), some other by-products are generated, such as (diethoxymethyl)benzene, 1,2-diphenylethene, 2,3-diphenyloxirane, and 1-(3,5-dimethoxyphenyl)propan-1-one. The slight difference between these two catalysts is generation of 3-phenylbenzofuran when the catalyst is changed from Cs-PW to Cs-SiW.

\subsection{Hydrogen donation reaction of the AE solvent}

\subsubsection{Reactions of pure $A E$}

As well as all of the reactions of 2-PAP with and without a catalyst, the products of dehydrogenation/dehydration of $\mathrm{AE}$ can also be generated, such as ethylal, ethoxyethene, diethyl ether, and acetal, accompanied by active hydrogen liberation $[15,53,63]$. Active hydrogen plays a crucial role in conversion of 2-PAP [53]. Therefore, promotion of conversion of AE by the POM catalysts was first investigated in the absence of 2-PAP.

Table 5 shows generation of ethoxyethene/acetal from pure $\mathrm{AE}$ with increasing temperature at a stirring speed of 300 $\mathrm{r} / \mathrm{min}$. As shown in Table 5, no dehydrogenated species of $\mathrm{AE}$ are detected before treatment (row 1). However, after treat-

\section{Table 5}

Generation of ethoxyethene/acetal with increasing temperature accompanied by liberation of active hydrogen without a catalyst a.

\begin{tabular}{lccc}
\hline Temperature $\left({ }^{\circ} \mathrm{C}\right)$ & Areaethoxyethene & Area $_{\text {acetal }}$ & Total area \\
\hline Untreated & n.d. & n.d. & 0 \\
200 & n.d. & 165743 & 165743 \\
240 & n.d. & 177070 & 177070 \\
260 & 27411 & 304464 & 331875 \\
280 & 143567 & 519981 & 663548 \\
\hline
\end{tabular}

a Reaction conditions: $50 \mathrm{~mL}$ pure $\mathrm{AE}, \mathrm{N}_{2}$ atmosphere, reaction time $4 \mathrm{~h}$, no catalyst, stirring speed $300 \mathrm{r} / \mathrm{min}$.

$\mathrm{b}^{\mathrm{T}}$ Total area $=$ area $_{\text {ethoxyethene }}+$ area $_{\text {acetal }}$. ment, ethoxyethene and acetal are detected (rows 3 and 4). Furthermore, the total area of generated ethoxyethene/acetal increases as the temperature increases (column 4). Remarkably, when the temperature is higher than $260^{\circ} \mathrm{C}$, the total GC-FID peak area of ethoxyethene and acetal significantly increases.

After addition of Cs-PMo to the system, the amounts of ethoxyethene and acetal significantly increase (Table 6). The total peak area of ethoxyethene and acetal in the GC-FID chromatogram increases to 1054547 in the post-reaction solvent compared with 165743 (Table 5) for the case without a catalyst at $200{ }^{\circ} \mathrm{C}$. In addition, the value at $280{ }^{\circ} \mathrm{C}$ is 4 times higher than that without Cs-PMo, meaning that Cs-PMo greatly accelerates dehydrogenation of ethanol. The Cs-SiW catalyst, which has weaker redox properties and a higher acid amount than Cs-PMo, was used to further investigate the effect of the acidity on the dehydrogenation reactions (row 5 of Table 6). Cs-SiW also increases the total amount of generated ethoxyethene/acetal compared with the data without a POM catalyst (row 5 of Table 5), and the increase is mainly because of enhancement of production of ethoxyethene.

The proposed mechanism is summarized in Scheme A $[64,65]$. First, ethanol is dehydrogenated to generate ethylal by a catalytic redox or self-redox reaction. Ethylal is then tautomerized to vinyl alcohol, which then reacts with ethanol to give

Table 6

Generation of ethoxyethene and acetal accompanied by liberation of active hydrogen with Cs-POM catalysts a

\begin{tabular}{lccrc}
\hline Catalyst & Temperature $\left({ }^{\circ} \mathrm{C}\right)$ & Area ethoxyethene & Area acetal & Total area ${ }^{\mathrm{b}}$ \\
\hline Cs-PMo & 200 & 103972 & 950575 & 1054547 \\
Cs-PMo & 240 & 222500 & 1013524 & 1236024 \\
Cs-PMo & 260 & 341989 & 2011751 & 2353740 \\
Cs-PMo & 280 & 782342 & 1966455 & 2748797 \\
Cs-SiW & 280 & 357394 & 482593 & 839987 \\
\hline
\end{tabular}

a Reaction conditions: $50 \mathrm{~mL}$ pure AE, reaction time $4 \mathrm{~h}, 0.010 \mathrm{~g} \mathrm{Cs-POM}$ catalyst, stirring speed $300 \mathrm{r} / \mathrm{min}$.

${ }^{\mathrm{b}}$ Total area $=$ areaethoxyethene + areaacetal. 
I. The generation of ethylal and ethoxyethene

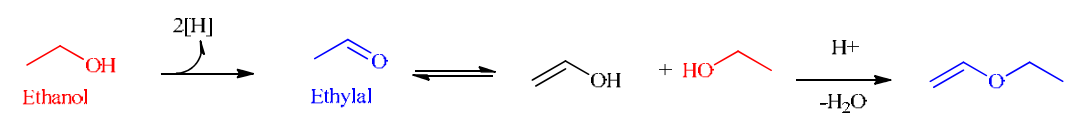

2. The generation of acetal

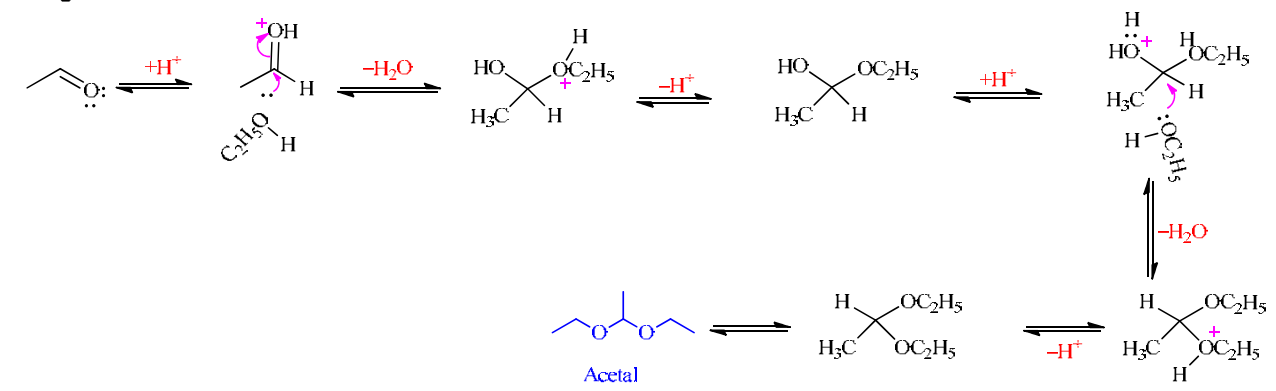

3. The generation of diethyl ether

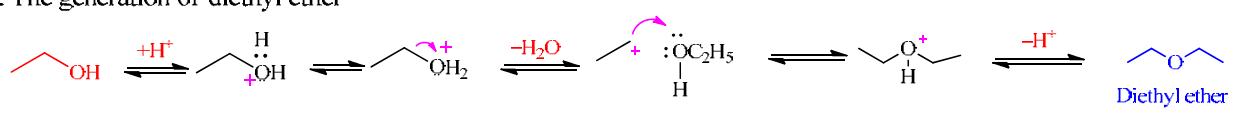

4. The reversity of acetal

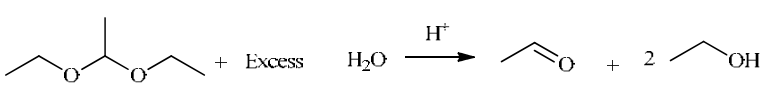

Scheme A. Proposed mechanisms for generation of ethylal, ethoxyethene, acetal, and diethyl ether accompanied by generation of active hydrogen.

ethoxyethene by an intermolecular dehydration reaction $(1$ in Scheme A). The carbonyl oxygen of ethylal can be attacked by a proton (from the acid) to generate an oxonium cation, which is susceptible to nucleophilic attack by the lone electron pair of oxygen in an ethanol molecule $[64,65]$. Hemiacetal is then generated after elimination of one water molecule and one proton. Hemiacetal is reactive with ethanol and undergo further acetylation to generate acetal, which is why no hemiacetal is detected in our products ( 2 in Scheme A). A small amount of diethyl ether is also detected in the post-reaction solutions and its generation mechanism is shown in 3 of Scheme A [61]. Because generation of diethyl ether is only because of intermolecular dehydration of two ethanol molecules and no active hydrogen is liberated, the amount of diethyl ether is not included in the "Total area" columns of Tables 3,5, and 6 as the estimate of the amount of liberated active hydrogen. This mechanism can explain the above reaction results where both the acidity and redox properties of the catalyst can accelerate conversion of $\mathrm{AE}$ with an increase in the dehydrogenating/dehydrating products of AE. Liberation of active hydrogen accompanying these reactions will be shown to be the key factor for decomposition of 2-PAP (Scheme B).

\subsubsection{Hydrogen generation in the system with 2-PAP}

By comparing the total GC-FID peak areas after the reaction (column 8 of Table 3), it is clear that addition of POMs in the reaction system containing 2-PAP and $\mathrm{AE}$ solvent increases active hydrogen liberation. The total area of ethoxyethene and acetal increases from 847253 without a POM catalyst to 1145881, 1257376, and 5888967 when Cs-SiW, Cs-PW, and Cs-PMo are added to the reaction system, respectively.

Considering the characterization results of the POMs (Section 3.1), the order of the amounts of acid sites is Cs-PMo > $\mathrm{Cs}-\mathrm{SiW}>\mathrm{Cs}-\mathrm{PW}$, the order of the acid strengths is Cs-PW $\geq$
Cs-SiW > Cs-PMo, and the order of the redox abilities is Cs-PMo $>$ Cs-PW $\geq$ Cs-SiW. The first concern is whether the acidity or the redox properties of the catalyst governs the dehydrogenation reaction of ethanol. Comparing the data given in column 5 of Table 5 and column 5 of Table 6 , it could be inferred that the acidity of the catalyst can lead to an increase of the total peak area of ethoxyethene and acetal, and such enhancement mainly comes from an increase in the amount of ethoxyethene. The effect of the amount of acid sites was further investigated in the system with 2-PAP by comparing the results of Cs-PW and Cs-SiW (column 8 of Table 3) because of the clear differences in their acid strengths (Fig. 4) and redox properties (Fig. 5) is slight. The difference in the total production of ethoxyethene and acetal is not very large $(\sim 10 \%)$ even though the acid amount of Cs-SiW is $60 \%$ higher than that of Cs-PW. However, the amount of dehydrogenated solvent products over Cs-PMo, which has the highest redox ability, is remarkably higher than (as much as 3.3 times) that of Cs-SiW, even though the former has the weakest acid strength and only 50\% more acid sites than the latter (Table 6). This indicates that the redox ability might dominate generation of active hydrogen by dehydrogenation of AE.

The effect of hydrogen transfer on the self-redox equilibrium of dehydrogenation-hydrogenation of ethanol was also investigated. As shown in row 5 of Table 6 and row 4 of Table 3, transfer of active hydrogen to 2-PAP and its intermediates can promote production of ethoxyethene and acetal through ethylal

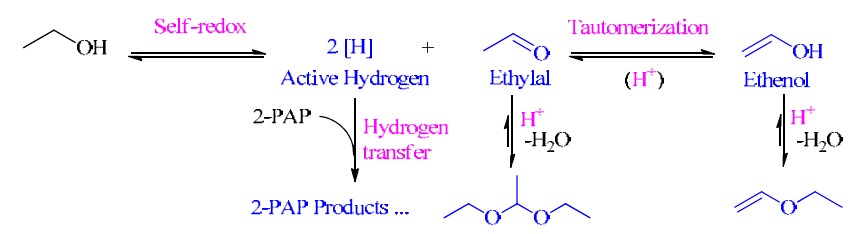

Scheme B. Summary of the self-redox equilibrium reactions of AE. 
generation. The difference of the total areas of ethoxyethene/acetal with and without a catalyst is about $30 \%$. Generation of ethoxyethene/acetal is remarkably enhanced when Cs-PMo is used (column 4 of Table 6 and column 2 of Table 3). The resulting $120 \%$ increase in generation of ethoxyethene/acetal can be ascribed to the high hydrogen transfer ability of Cs-PMo [58,66]. Scheme B summarizes promotion of hydrogen transfer and acid catalysis in the redox reaction of AE.

\subsection{Reaction of 2-PAP in AE catalyzed by POMs}

\subsubsection{Reaction mechanism of 2-PAP in $A E$}

2-PAP would react with the liberated active hydrogen accompanying dehydrogenation of $\mathrm{AE}$ to form various products even if no other catalyst is added (Section 3.2). The hydrogen transfer mechanism was proposed in our previous paper from the product distribution in the system without adding a catalyst [53]. However, some new products, such as 3-phenylbenzofuran, 2-phenylethan-1-ol, and 1,2-diphenylethene, are observed when acidic POMs are used as a catalyst (Table 4, Fig. 7). Therefore, we propose the acid-catalyzed reaction pathways beyond the hydrogen transfer mechanism in Scheme C.

When an acid catalyst exists in the reaction system, the lone pair electrons on the oxygen of the ether linkage in 2-PAP are susceptible to attack by a proton from the acid catalyst to form an oxonium cation [59] along route I (Scheme C). The formed oxonium cation can be temporarily stabilized by coordination to POMs anions $[46,65,67,68]$, or even be attacked by a water molecule (if water is present as a nucleophilic agent) to give phenol and 2-hydroxy-1-phenylethan-1-one [69]. 2-Hydroxy-1-phenylethan-1-one can then be hydrogenated and dehydrated to 2-phenylethan-1-ol over an acid catalyst [70]. If the 2-PAP molecule is attacked by a proton at the $\alpha$-carbonyl group, conversion can proceed along route II in Scheme $C$ to form a 1-hydroxy-2-phenoxy-1-phenylethan-1-ylium cation, which can also be temporarily stabilized by coordination to POM anions in an anhydrous environment $[46,65,67,68]$, or further cyclized and transform to 3-phenylbenzofuran. Some other products, such as 2,3-diphenyloxirane, 1,2-diphenylethene, and (2,2-diethoxyethyl)benzene, can be considered as the acid-catalyzed products obtained from hydrogen transfer reactions. The generated 2-hydroxy-1,2-diphenylethan-1-one can be hydrogenated to a 1,2-diphenylethane-1,2-diol (route IV) and further transform to 2,3-diphenyloxirane along route IVa or 1,2-diphenylethene along route $\mathrm{IVb}$. The product (2,2-diethoxyethyl)benzene can be considered to be generated along route $\mathrm{V}$ by reaction of pre-generated styrene (product of route III) with ethanol molecules [71]. The generation mechanism of 1-(3,5-dimethoxyphenyl)propan-1-one is not clear under our

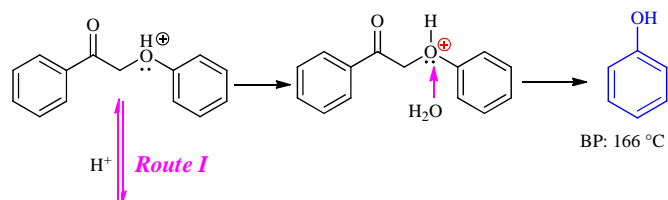

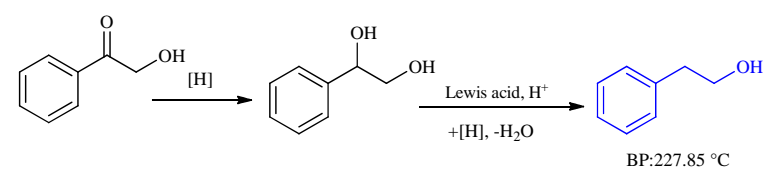

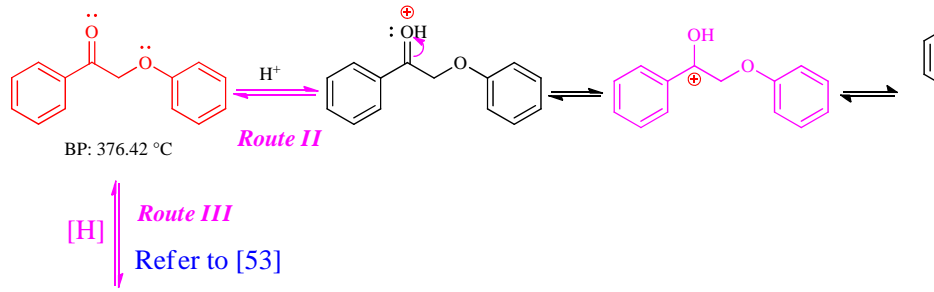<smiles>CC(=O)c1ccccc1</smiles><smiles>C=Cc1ccccc1</smiles><smiles>CCOC(C(=O)c1ccccc1)c1ccccc1</smiles><smiles>OC(COc1ccccc1)c1ccccc1</smiles>

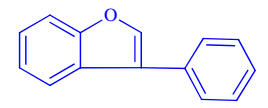

BP: $329.15^{\circ} \mathrm{C}$

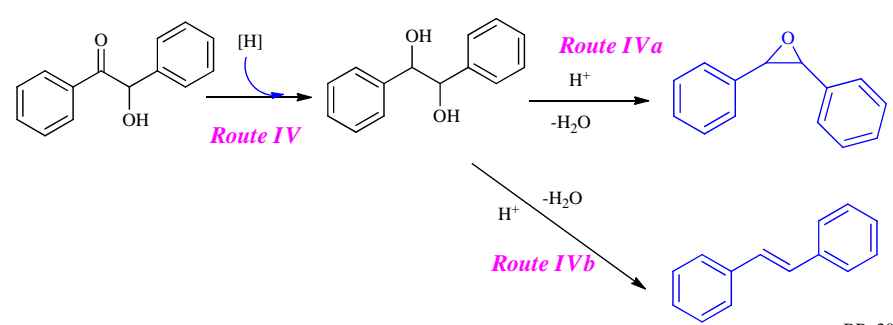<smiles>C=Cc1ccccc1</smiles><smiles>CCOC(Cc1ccccc1)OCC</smiles>
BP: $272.09^{\circ} \mathrm{C}$

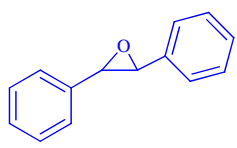

BP: $329.15^{\circ} \mathrm{C}$ BP: $304.29^{\circ} \mathrm{C}$

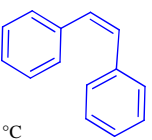

BP: Boiling point

Scheme C. Proposed mechanisms for generation of some of the main products of 2-PAP in AE catalyzed by Cs-PW or Cs-SiW. 
reaction conditions (Table 4 and Fig. 7).

\subsubsection{Interpretation of 2-PAP transformation over the POMs}

The experimental results in Section 3.2 (Tables 3 and 4, Fig. 7) show the dramatic differences in 2-PAP conversion, the product selectivities, and the product distributions over different POM catalysts. This can be explained by associating the reaction results with the reaction mechanism and the properties of the POMs.

(1) Conversion of 2-PAP in AE (column 3 of Table 3). As shown in Table 2, the reaction of 2-PAP in AE shows dramatically different conversion over different POM catalysts. Both the reactions without a catalyst and with the Cs-PMo catalyst have high conversion of $>99 \%$. However, addition of Cs-PW decreases the conversion of 2-PAP to $88.8 \%$, while it greatly decreases to $37.6 \%$ when Cs-SiW is added. We speculated that $\mathrm{Cs}-\mathrm{SiW}$ and Cs-PW can promote the reverse-cleavage reaction, that is, the condensation reaction of phenol with acetophenone. Thus, a reaction was performed with these two reactants in $\mathrm{AE}$ using the Cs-SiW catalyst (Table 7 and Fig. 8). The reverse reaction did not occur. Both phenol and acetophenone were stable and only a small part of acetophenone was hydrogenated to 1-phenylethan-1-ol or its derivatives, such as styrene (Table 7 and Fig. 8). This reaction confirmed the mechanism for generation of 1-phenylethan-1-ol proposed in Scheme 2 in our previous report [53], although the speculation about the reverse reaction mechanism was false.

Considering the characterization results of the POMs and combining them with previous results $[41,46,54,65,68,72]$, it is clear that these three POMs have very different acid strengths, acid site amounts, and redox properties. Considering the order of the active hydrogen amounts in Table 2 (Cs-PMo > Cs-SiW $\geq$ Cs-PW) and the proposed scheme for conversion of 2-PAP [53], conversion of 2-PAP is clearly enhanced as the active hydrogen donating ability increases, whereas it is inhibited with increasing amount of acid sites and acid strength (Figs. 4-7, and Tables 2 and 3). The former was demonstrated in our previous report [53], while the latter can be explained as follows. Under cataly-

\section{Table 7}

Product distribution of phenol and acetophenone in AE before and after treatment at $280^{\circ} \mathrm{C}$ for $4 \mathrm{~h}$ with Cs-SiW as the catalyst.

\begin{tabular}{|c|c|c|}
\hline Product & $\begin{array}{c}\text { Before processed } \\
\text { area }^{\text {a }}\end{array}$ & $\begin{array}{c}\text { After processed } \\
\text { area }\end{array}$ \\
\hline & u.d. & 34734 \\
\hline & u.d. & 2391387 \\
\hline & u.d. & 85431 \\
\hline & 2535273 & 2406059 \\
\hline & u.d. & 498623 \\
\hline & 3190164 & 2391387 \\
\hline 2-PAP & u.d. & u.d. \\
\hline
\end{tabular}

${ }^{a}$ Areas of the corresponding peaks from GC-FID.

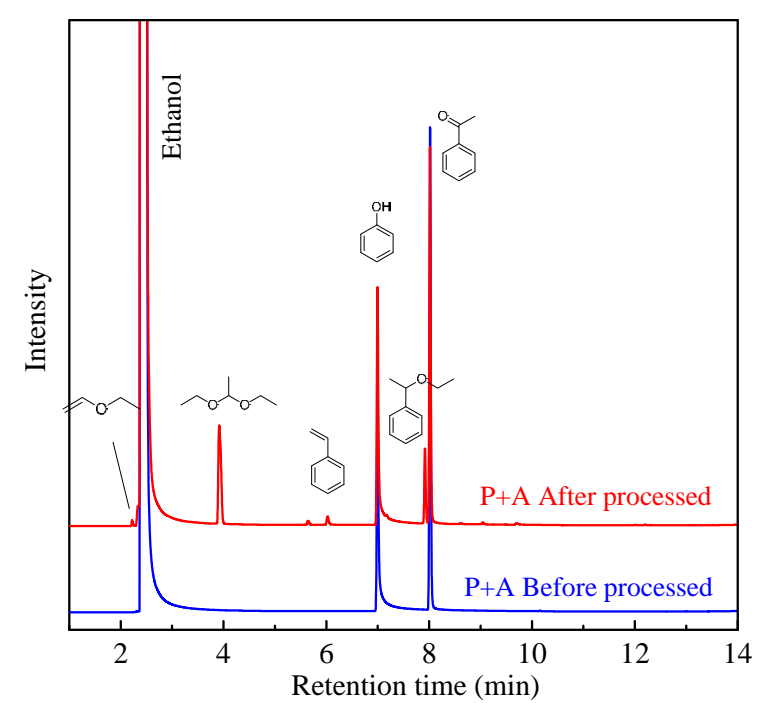

Fig. 8. GC-FID profiles of phenol and acetophenone in AE before and after decomposition at $280^{\circ} \mathrm{C}$ for $4 \mathrm{~h}$ with $\mathrm{Cs}$-SiW as the catalyst.

sis with a strong acid, the 2-PAP molecule can form an oxonium cation at the $\alpha$-carbonyl and/or ether bond oxygen atom (route I or II in Scheme C) $[64,65]$, and this oxonium cation can then be stabilized by the anion of the POM $[46,54,64,65,68,72,73]$. The competition between this stabilization effect of the oxonium cation and the ability for active hydrogen transfer of the catalyst [53] dominates conversion of 2-PAP.

When the active hydrogen donating and transfer ability is strong but there are few weak acid sites, conversion of 2-PAP would proceed along the hydrogen transfer route, similar to the reaction of 2-PAP in AE or IPA without a catalyst [53]. Similarly, when the active hydrogen donating and transfer ability is very strong but the acidity strength is not very strong, similar to the case with the Cs-PMo catalyst, conversion of 2-PAP would also proceed along the active hydrogen transfer route (Tables 3-6 and Figs. 4-7). However, if the strength of the acid sites is very strong and the acid site amount is very large, conversion of 2-PAP would proceed along the oxonium cation mechanism, such as the reaction of 2-PAP in AE with the Cs-PW catalyst (Tables 3-6 and Figs. 4-7) or Cs-SiW catalyst (Tables 3 and 4, and Fig. 7).

(2) Selectivities of the desired products. The selectivities of the various products depend on their reaction routes and reaction rates. When 2-PAP reacts in $\mathrm{AE}$ without adding a catalyst, the selectivities of phenol and acetophenone are $81.6 \%$ and $54.4 \%$, respectively, and the total mass yield of other byproducts is $33.0 \%$ (Table 3). Addition of the Cs-PMo catalyst further enhances the selectivities to phenol and acetophenone to $98.6 \%$ and $91.1 \%$, respectively, with 2 -PAP conversion of $>$ $99 \%$ and the mass yield of other products of $<5 \%$ (Table 3 ). This can be explained by our reaction mechanism and the detailed product distribution (columns 2 and 3 of Table 3). When Cs-PMo is added, the by-products generated along route Ib in Scheme 2 in [53] are not present, and the desired products of phenol and acetophenone are produced with in small amounts excessive hydrogenated products, such as (1-ethoxyethyl)benzene, styrene, ethylbenzene, and 
2-phenoxy-1-phenylethan-1-ol. The by-products of isomerization, rearrangement, and oxidization are also not present. Considering Tables 3-6, active hydrogen generation greatly increases when Cs-PMo is added, which can be attributed to its strong redox properties. Cs-PMo not only enhances generation of active hydrogen, but it can also promote hydrogen transfer to the intermediates $[66,74-77]$. Therefore, Cs-PMo can promote the reaction along route Ia to generate the desired products (Scheme 2 in [53]). Moreover, the acid strength of Cs-PMo is not very high and isomerization and rearrangement of the intermediates rarely occurs. As a result, Cs-PMo exhibits excellent selectivity for the desired products with almost complete conversion of 2-PAP.

When the Cs-PW catalyst is used, the selectivities to phenol and acetophenone are both lowered and 2-PAP conversion is also lowered (Table 3). Analyzing the results in Tables 3 and 4, some side products are generated by a pathways other than the hydrogen transfer mechanism, such as (diethoxymethyl)benzene, 1-(3,5-dimethoxyphenyl)propan-1-one, 1,2-diphenylethene, and 2,3-diphenyloxirane (columns 2 and 4 of Table 4). This shows that a portion of the reaction of 2-PAP proceeds along the acid-catalyzed route (routes II-IV in Scheme C) $[64,65]$. Because the amount of acid sites is not too much (Table 2), most of 2-PAP can be converted by the hydrogen transfer mechanism. The selectivities to the desired products decreases with conversion. When the Cs-SiW catalyst is used, the selectivities to phenol and acetophenone are $40.7 \%$ and $11.3 \%$ with 2-PAP conversion of only $37.6 \%$ (row 4 of Table 3). From the product distribution given in Table 4 , the probable products generated by the hydrogen transfer mechanism are generated owing to enhanced hydrogen donation from AE compared with the case without a catalyst (Table 3). Some new products are also generated, such as (diethoxymethyl)benzene, 1,2-diphenylethene, 2,3-diphenyloxirane, 3-phenylbenzofuran, and 2-phenylethan-1-ol. This can be attributed to an increased portion of the reaction of 2-PAP proceeding by the acid-catalyzed mechanism. Careful analysis of proposed Scheme $\mathrm{C}$ and the product distribution in Table 4 shows that there are considerably more side reactions derived from acetophenone along route $\mathrm{V}$ and less reaction along route III (Scheme C). These phenomena lead to a low yield of acetophenone and a very high $S_{\mathrm{P}} / S_{\mathrm{A}}$ ratio (row 4 of Table 3 ).

\section{Conclusions}

Decomposition of the lignin model compound 2-PAP in AE has been investigated using three POM catalysts. Cleavage of 2-PAP can follow either an active hydrogen transfer mechanism or an oxonium cation mechanism. The product distribution depends on the competition between the hydrogen donating ability and the acid strength/amount. The function of the POM catalyst is to promote active hydrogen liberation and promote formation and temporary stabilization of oxonium cations. The Cs-PMo catalyst can also increase the hydrogen donating ability and promote hydrogen transfer to the reaction intermediates, leading to high conversion of 2-PAP (>99\%) and excellent selectivities to the desired products $(98.6 \%$ for phe- nol and $91.1 \%$ for acetophenone). An acid catalyst with very strong acid strength and high amount of acid sites can have an inhibitory effect on the decomposition reactions of 2-PAP; that is, it can inhibit conversion and lower the product selectivities.

\section{References}

[1] U.S. Department of Agriculture, USDA Announces Investments in Bioenergy Research and Development to Spur New Markets, Innovation, and Unlimited Opportunity in Rural America, 2013.

[2] IRENA (2014): REmap 2030: A Renewable Energy Roadmap, IRENA: Abu Dhabi, 2014.

[3] D. S. Argyropoulos, Materials, Chemicals, and Energy from Forest Biomass, American Chemical Society; Oxford University Press, 2007.

[4] J. van Haveren, E. L. Scott, J. Sanders, Biofuels Bioprod. Bioref., 2008, 2, 41-57.

[5] T. Werpy, G. Peterson, A. Aden, J. Bozell, J. Holladay, J. White, A. Manheim, D. Eliot, L. Lasure, S. Jones, Top Value Added Chemicals from Biomass, 2004, Vol. 1.

[6] T. E. Amidon, S. J. Liu, Biotechno. Adv., 2009, 27, 542-550.

[7] C. Heitner, D. R. Dimmel, J. A. Schmidt, Lignin \& Lignans Advances in Chemistry, CRC Press, 2010.

[8] S. M. Kang, X. L. Li, J. Fan, J. Chang, Renew. Sust. Energ. Rev., 2013, 27, 546-558.

[9] J. Zakzeski, A. L. Jongerius, P. C. A. Bruijnincx, B. M. Weckhuysen, ChemSusChem, 2012, 5, 1602-1609.

[10] K. De Oliveira-Vigier, N. Abatzoglou, F. Gitzhofer, Can. J. Chem. Eng., 2005, 83, 978-984.

[11] P. J. Deuss, K. Barta, Coord. Chem. Rev., 2016, 306, 510-532.

[12] C. Z. Li, X. C. Zhao, A. Q. Wang, G. W. Huber, T. Zhang, Chem. Rev., 2015, 115, 11559-11624.

[13] R. Rinaldi, R. Jastrzebski, P. C. A. Bruijnincx, B. M. Weckhuysen, M. Kennema, M. T. Clough, J. Ralph, Angew. Chem. Int. Ed., 2016, 55, 8164-8215.

[14] S. Dutta, K. C. W. Wu, B. Saha, Catal. Sci. Technol., 2014, 4, 3785-3799.

[15] Q. Song, F. Wang, J. Y. Cai, Y. H. Wang, J. J. Zhang, W. Q. Yu, J. Xu, Energy Environ. Sci., 2013, 6, 994-1007.

[16] R. Ma, W. Y. Hao, X. L. Ma, Y. Tian, Y. D. Li, Angew. Chem. Int. Ed., 2014, 53, 7310-7315.

[17] X. L. Ma, R. Ma, W. Y. Hao, M. M. Chen, F. Iran, K. Cui, Y. Yan, Y. D. Li, ACS Catal., 2015, 5, 4803-4813.

[18] A. Narani, R. K. Chowdari, C. Cannilla, G. Bonura, F. Frusteri, H. J. Heeres, K. Barta, Green Chem., 2015, 17, 5046-5057.

[19] J. Mottweiler, M. Puche, C. Raeuber, T. Schmidt, P. Concepcion, A. Corma, C. Bolm, ChemSusChem, 2015, 8, 2106-2113.

[20] L. Yang, Y. D. Li, P. E. Savage, Ind. Eng. Chem. Res., 2014, 53, 2633-2639.

[21] W. P. Deng, H. X. Zhang, L. Q. Xue, Q. H. Zhang, Y. Wang, Chin. J. Catal., 2015,36, 1440-1460.

[22] Z. C. Jiang, C. W. Hu, J. Energy Chem., 2016, 25, 947-956.

[23] Y. Y. Ma, Z. T. Du, J. X. Liu, F. Xia, J. Xu, Green Chem., 2015, 17, 4968-4973.

[24] H. W. Guo, B. Zhang, Z. J. Qi, C. Z. Li, J. W. Ji, T. Dai, A. Q. Wang, T. Zhang, ChemSusChem, 2017, 10, 523-532.

[25] J. G. Zhang, H. Asakura, J. van Rijn, J. Yang, P. Duchesne, B. Zhang, X. Chen, P. Zhang, M. Saeys, N. Yan, Green Chem., 2014, 16, 2432-2437.

[26] M. Zaheer, R. Kempe, ACS Catal., 2015, 5, 1675-1684.

[27] C. Peng, Q. Chen, H. W. Guo, G. Hu, C. Z. Li, J. L. Wen, H. S. Wang, T. 


\section{Graphical Abstract}

Chin. J. Catal., 2017, 38: 1216-1228 doi: 10.1016/S1872-2067(17)62854-7

Decomposition of a $\beta$-0-4 lignin model compound over solid Cs-substituted polyoxometalates in anhydrous ethanol: acidity or redox property dependence?

Xuezhong Wu, Wenqian Jiao, Bing-Zheng Li, Yanming Li, Yahong Zhang, Quanrui Wang, Yi Tang *

Fudan University; Guangxi Academy of Sciences

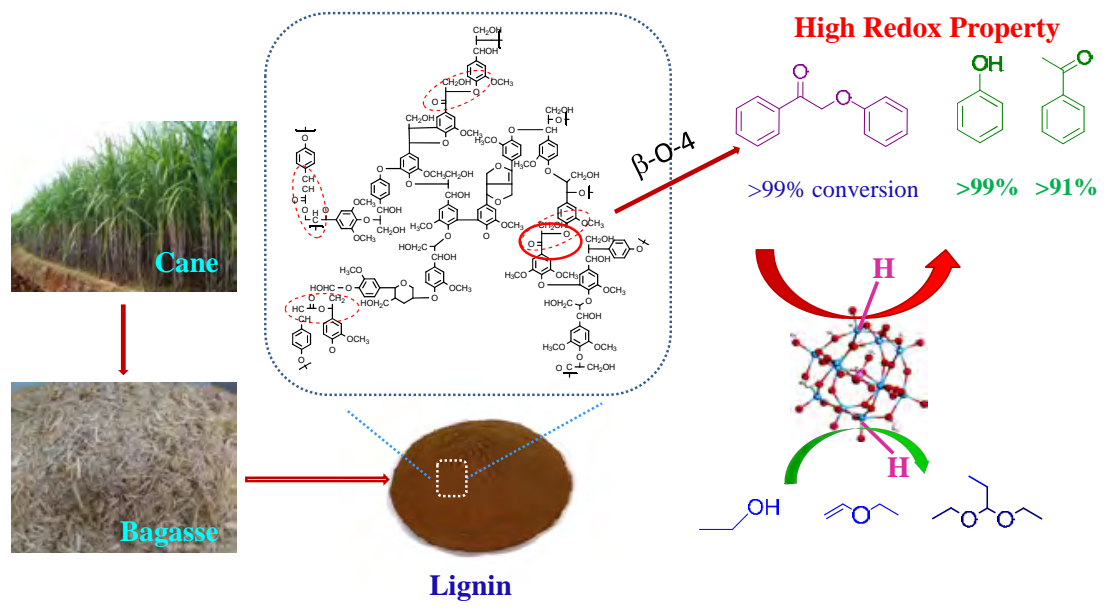

The lignin model compound 2-phenoxyacetophenone can be completely cleaved into target products in a hydrogen-donating atmosphere over a catalyst with strong redox properties by the hydrogen transfer mechanism.

Zhang, Z. B. K. Zhao, R. C. Sun, H. B. Xie, ChemCatChem, 2017, 9, $1135-1143$.

[28] H. W. Guo, B. Zhang, C. Z. Li, C. Peng, T. Dai, H. B. Xie, A. Q. Wang, T. Zhang, ChemSusChem, 2016, 9, 3220-3229.

[29] H. Konnerth, J. G. Zhang, D. Ma, M. H. G. Prechtl, N. Yan, Chem. Eng. Sci., 2015, 123, 155-163.

[30] X. L. Ma, Y. Tian, W. Y. Hao, R. Ma, Y. D. Li, Appl. Catal. A, 2014, 481, 64-70.

[31] N. Yan, Y. A. Yuan, R. Dykeman, Y. A. Kou, P. J. Dyson, Angew. Chem. Int. Ed., 2010, 49, 5549-5553.

[32] Z. C. Luo, Y. M. Wang, M. Y. He, C. Zhao, Green Chem., 2016, 18, 433-441.

[33] A. Berlin, M. Balakshin, N. Gilkes, J. Kadla, V. Maximenko, S. Kubo, J. Saddler, J. Biotechnol, 2006, 125, 198-209.

[34] H. J. Li, Y. Q. Pu, R. Kumar, A. J. Ragauskas, C. E. Wyman, Biotechnol. Bioeng., 2014, 111, 485-492.

[35] Z. Strassberger, A. H. Alberts, M. J. Louwerse, S. Tanase, G. Rothenberg, Green Chem., 2013,15, 768-774.

[36] J. Zhang, Y. Liu, S. Chiba, T. P. Loh, Chem. Commun., 2013, 49, 11439-11441.

[37] Y. Y. Jiang, L. Yan, H. Z. Yu, Q. Zhang, Y. Fu, ACS Catal., 2016, 6, 4399-4410.

[38] H. F. Liu, M. Wang, H. J. Li, N.C. Luo, S. T. Xu, F. Wang, J. Catal., 2017, 346, 170-179.

[39] M. Wang, L. H. Li, J. M. Lu, H. J. Li, X. C. Zhang, H. F. Liu, N. C. Luo, F. Wang, Green Chem., 2017, 19, 702-706.

[40] M. Wang, J. M. Lu, X. C. Zhang, L. H. Li, H. J. Li, N. C. Luo, F. Wang, ACS Catal., 2016, 6, 6086-6090.

[41] N. Mizuno, M. Misono, Chem. Rev., 1998, 98, 199-218.

[42] J. J. Bozell, J. O. Hoberg, D. R. Dimmel, J. Wood Chem. Technol., 2000, 20, 19-41.

[43] H. W. Park, S. Park, D. R. Park, J. H. Choi, I. K. Song, Korean J. Chem.
Eng., 2011, 28, 1177-1180.

[44] J. K. Kim, H. W. Park, U. G. Hong, J. H. Choi, I. K. Song, J. Nanosci. Nanotechno., 2014, 14, 8884-8890.

[45] Y. T. Cheng, J. Jae, J. Shi, W. Fan, G. W. Huber, Angew. Chem. Int. Ed., 2012, 51, 1387-1390.

[46] M. T. Pope, A. Müller, Polyoxometalate Chemistry from Topology via Self-Assembly to Applications, Kluwer Academic Publishers, Boston, 2001.

[47] A. J. Bridgeman, Chem. Phys., 2003, 287, 55-69.

[48] A. J. Bridgeman, Chem. Eur. J., 2004, 10, 2935-2941.

[49] K. N. Rao, K. M. Reddy, N. Lingaiah, I. Suryanarayana, P. S. S. Prasad, Appl. Catal. A, 2006, 300, 139-146.

[50] F. J. Berry, G. R. Derrick, M. Mortimer, Polyhedron, 2014, 68, $17-22$.

[51] M. Langpape, J. M. M. Millet, U. S. Ozkan, M. Boudeulle, J. Catal., 1999, 181, 80-90.

[52] B. M. Devassy, S. B. Halligudi, J. Mol. Catal. A, 2006, 253, 8-15.

[53] X. Z. Wu, W. Q. Jiao, Y. M. Li, B. Z. Li, Y. H. Huang, H. B. Zhang, Y. H. Zhang, Q. R. Wang, Y. Tang, Bioresources, 2016, 11, 10349-10377.

[54] I. V. Kozhevnikov, Chem. Rev., 1998, 98, 171-198.

[55] J. L. Brito, J. Laine, K. C. Pratt, J. Mater. Sci., 1989, 24, 425-431.

[56] S. Rajagopal, H. J. Marini, J. A. Marzari, R. Miranda, J. Catal., 1994, $147,417-428$.

[57] D. Gazzoli, F. Prinetto, M. C. Campa, A. Cimino, G. Ghiotti, V. Indovina, M. Valigi, Surf. Interface Anal., 1994, 22, 398-402.

[58] D. P. Debecker, B. Schimmoeller, M. Stoyanova, C. Poleunis, P. Bertrand, U. Rodemerck, E. M. Gaigneaux, J. Catal., 2011, 277, 154-163.

[59] Y. Sun, W. Wang, J. W. Qin, D. Zhao, B. G. H. Mao, Y. Xiao, M. Cao, Electrochim. Acta, 2016, 187, 329-339.

[60] A. P. Shpak, A. M. Korduban, M. M. Medvedskij, V. O. Kandyba, J. Electron Spectrosc., 2007, 156-158, 172-175. 
[61] D. Varisli, T. Dogu, G. Dogu, Chem. Eng. Sci., 2007, 62, 5349-5352.

[62] M. Iwamoto, Catal. Today, 2015, 242, 243-248.

[63] M. J. Gilkey, B. J. Xu, ACS Catal., 2016, 6, 1420-1436.

[64] F. A. Carey, R. J. Sundberg, Advanced Organic Chemistry, 5th ed., Springer, New York, 2007.

[65] P. Vollhardt, N. Schore, Organic Chemistry: Structure and Function, W. H. Freeman, 2011.

[66] X. W. Sha, L. Chen, A. C. Cooper, G. P. Pez, H. S. Cheng, J. Phys. Chem. C, 2009, 113, 11399-11407.

[67] H. Hattori, Y. Ono, Solid Acid Catalysis: from Fundamentals to Applications, CRC Press, Boca Raton, FL, 2015.

[68] M. Misono, Catal. Rev. Sci. Eng., 1987, 29, 269-321.

[69] D. S. Matharu, D. J. Morris, A. M. Kawamoto, G. J. Clarkson, M. Wills, Org. Lett., 2005, 7, 5489-5491.
[70] M. Orfanopoulos, I. Smonou, Synth. Commun., 1988, 18, 833-839.

[71] A. D. Chowdhury, G. K. Lahiri, Chem. Commun., 2012, 48, 3448-3450.

[72] M. L. Sarazen, E. Doskocil, E. Iglesia, J. Catal., 2016, 344, 553-569.

[73] R. Neumann, Polyoxometalate Complexes in Organic Oxidation Chemistry, Wiley, Weinheim, 1998.

[74] L. Chen, A. C. Cooper, G. P. Pez, H. S. Cheng, J. Phys. Chem. C, 2008, 112, 1755-1758.

[75] H. S. Cheng, L. Chen, A. C. Cooper, X. W. Sha, G. P. Pez, Energy Environ. Sci., 2008, 1, 338-354.

[76] A. I. Gavrilyuk, Appl. Surf. Sci., 2013, 273, 735-747.

[77] A. I. Gavrilyuk, M. M. Afanasiev, Sol. Energy Mater. Sol. Cells, 2009, 93, 280-288.

\title{
无水乙醇中 $\boldsymbol{\beta}-0-4$ 型木素模型物在铯取代的多氧金属盐上的降解: 酸性和氧化还原性的影响
}

\author{
吴学众 ${ }^{\mathrm{a}, \mathrm{b}}$, 焦文千 ${ }^{\mathrm{a}}$, 李秉正 ${ }^{\mathrm{b}}$, 黎演明 ${ }^{\mathrm{b}}$, 张亚红 ${ }^{\mathrm{a}}$, 王全瑞 ${ }^{\mathrm{c}}$, 唐 臨, ${ }^{\mathrm{a}}$, \\ a复旦大学化学系, 能原材料协同创新中心, 先进材料实验室, 上海分子催化与创新材料重点实验室, 上海200433 \\ $\mathrm{b}$ 广西科学院国家非粮生物质能源工程技术研究中心, 非粮生物质酶解国家重点实验室, 广西生物质工程技术研究中心, \\ 广西生物质产业化工程院, 广西生物炼制重点实验室, 广西南宁530007 \\ c复旦大学化学系, 上海200433
}

\begin{abstract}
摘要: 随着化石能源的日益减少, 从木质生物质获得能源、燃料和化学品变得至关重要. 木素是木质生物质的第二大主要 组分, 但是目前远未得到充分利用. 随着对木素结构的充分认识和相关催化科学技术的发展, 由木素制得大宗燃料或精细 化学品, 特别是芳香类化合物显示出越来越具有技术和经济可行性. 由于木质素大分子中复杂的 C-O和C-C连接, 先研究 模型物的断裂机理并同时考虑从木素模型物小分子迁移到木质素大分子的问题, 然后设计出合适的催化材料并开发出可 行的工艺过程, 这条技术路线看起来更具有可行性.

近年来, 几种均相或非均相多氧金属盐(Polyoxometalates (POMs), 或称杂多酸)用于降解木素或者木素模型物, 但是 $\beta-O-4$ 梄键断裂的氢解还是酸解机理及其竞争合作作用尚不清晰. 我们在几种多氧金属盐(POMs)的催化下研究了 $\beta-O-4$ 模 型物2-phenoxyacetophenone (2-PAP)在以无水乙醇作为供氢溶剂体系下的催化断裂机理和行为. 结果表明, 随着无水乙醇 溶剂处理温度的提高, 溶剂的供氢能力增强. 酸性催化剂的加入提高了溶剂供氢能力. 原因是催化剂的酸性改变了乙醇自 氧化还原反应的平衡, 使平衡向生成乙醛并释放出活性氢的方向进行. 我们还发现, Cs-PMo的氧化还原性, 对促进活性氢 的释放起更大的作用. 2-PAP反应底物的加入消耗了活性氢, 从而促使乙醇自氧化还原平衡向右移动.

在酸性催化剂的作用下, 2-PAP的转化裂解可以按照氢转移机制或酸催化的氧鎓离子机制进行. 大部分转化反应按照 哪个机制进行, 取决于所采用体系的供氢能力和酸强度/数量的竞争关系, 大部分反应将屈从于占竞争优势的机制. 在强供 氢及转移能力占优势, 而酸强较低酸量较少时, 反应主要按氢转移机制进行. 在酸强很强且数量较多, 反应将主要按酸催 化氧鎓离子机制进行. Cs-PMo这个拥有酸性和强氧化还原性的双功能催化剂的使用, 既促进了活性氢的释放, 又增强了活 性氢的还原能力及转移能力, 因而导致了在极高转化率(>99\%)的下极佳的选择性(98.6\%苯酚和 $91.1 \%$ 苯乙酮).

这些发现将对理解木质素中醚键的断裂结果和机理提供启示, 为设计开发出木质素选择性地催化裂解为芳香小分子 的可行的工业过程打下初步理论基础.
\end{abstract}

关键词: 木素模型物; $\beta-O-4$ 醚键; 多氧金属盐; 氢转移机理; 氧鎓离子机理; 无水乙醇

收稿日期: 2017-03-26. 接受日期: 2017-04-30. 出版日期: 2017-07-05.

*通讯联系人. 电话: (021)55664125; 传真: (021)65641740; 电子信箱: yitang@fudan.edu.cn

基金来源：国家重点基础研究发展计划(973计划, 2013CB934101); 国家自然科学基金(21433002, 21573046); 中国博士后科学基 金(2016M601492); 广西科学研究与技术开发计划(15104001-5).

本文的英文电子版由Elsevier出版社在ScienceDirect上出版(http://www.sciencedirect.com/science/journal/18722067). 